Int. J. Dev. Biol. 52: 769-780 (2008)

doi: $10.1387 / \mathrm{ijdb} .0825771 \mathrm{t}$

\title{
Causes and consequences of the evolution of reproductive proteins
}

\author{
LESLIE M. TURNER* and HOPI E. HOEKSTRA \\ Department of Organismic and Evolutionary Biology and The Museum of Comparative Zoology, Harvard University, \\ Cambridge, MA, USA
}

\begin{abstract}
Proteins involved in reproduction often evolve rapidly, raising the possibility that changes in these proteins contribute to reproductive isolation between species. We review the evidence for rapid and adaptive change in reproductive proteins in animals, focusing on studies in recently diverged vertebrates. We identify common patterns and point out promising directions for future research. In particular, we highlight the ways that integrating the different but complementary approaches of evolutionary and developmental biology will provide new insights into fertilization processes.
\end{abstract}

KEY WORDS: evo-devo, gamete, positive selection, reproductive isolation, fertilization proteins, speciation

\section{Introduction}

While the burgeoning field of "evo-devo" has formally united the study of evolution and development, the historical directions and approaches of these two fields have been distinct. A primary goal of evolutionary biology is to explain how genetic variation arises and is maintained in nature. While variation initially arises within populations, it is the variation between diverging populations that fuels speciation, and ultimately biological diversity. In contrast, developmental biology is concerned with the mechanisms by which an individual organism takes shape, processes that are generally highly conserved not only within species but often among widely divergent taxa. The study of fertilization, however, unites these two fields: traits associated with fertilization, a first and critical step in development common to all sexually reproducing organisms, are often remarkably variable between species and sometimes even within species. Consequently, fertilization is a process that is of common interest to both evolutionary and developmental biologists.

One of the most striking patterns observed in natural populations of animals is the rapid evolution of fertilization proteins. Although some of the earliest and most dramatic examples of rapid change in reproductive proteins were identified through studies of fertilization by developmental biologists (e.g., Lee and Vacquier, 1992), this pattern and its potential consequences have been embraced by evolutionary biologists. This is, in part, because rapid evolution of reproductive proteins can make an important contribution to reproductive isolation between diverging taxa, and under- standing reproductive isolation is the key to understanding speciation (Coyne and Orr, 2004). While rapid evolution and positive selection of reproductive proteins have been seen in many groups of animals and plants (Singh and Kulathinal, 2000; Swanson and Vacquier, 2002b; Clark et al., 2006), in most cases, the functional consequences of amino acid changes on fertilization potential are unknown. Tools used by developmental biologists provide the means to determine the precise effects of amino acid mutations on protein interactions, egg-sperm binding and fertilization success. Conversely, evolutionary analyses can provide new insights into the mechanics of fertilization. For example, sequence analyses can identify rapidly evolving protein regions that may be important in critical interactions during fertilization.

The earliest evidence for rapid evolution of reproductive proteins came from studies of abalones and sea urchins (reviewed in Kresge et al., 2001; Zigler et al., 2005; see article by Zigler in this issue). Additional work on reproductive protein evolution has since accumulated in diverse taxa. Evolutionary sequence analyses in insects (primarily Drosophila) and vertebrates have shown adaptive evolution of functionally diverse reproductive proteins. The molecular-evolution approaches commonly applied to detect adaptive evolution in vertebrates are most statistically powerful when widely divergent sequences are compared; therefore studies of vertebrate reproductive proteins within groups of closely related

\footnotetext{
Abbreviations used in this paper: AV, acrosomal vesicle; EC, egg cytoplasm; VE, vitelline envelope; VERL, vitelline envelope receptor for lysin.
}

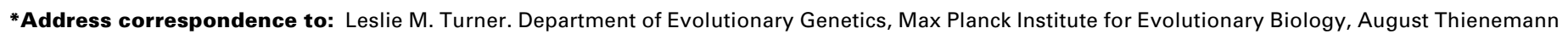
Str. 2, 24306 Ploen, Germany. Fax: +49 45022-763287. e-mail: turner@evolbio.mpg.de
} 
TABLE 1

\section{STUDIES OF REPRODUCTIVE PROTEIN EVOLUTION IN CLOSELY RELATED SPECIES}

\begin{tabular}{|c|c|c|c|c|}
\hline Taxon & Protein & Function & Result & Reference \\
\hline \multicolumn{5}{|l|}{ Marine invertebrates } \\
\hline sea urchins (Echinometra) & bindin $(S)$ & egg vitelline-envelope (VE) binding & $\mathrm{HP}, \mathrm{BS}$ & $\begin{array}{c}\text { (Lessios and Cunningham, 1990; McCartney and } \\
\text { Lessios, 2004) }\end{array}$ \\
\hline sea urchins (Echinometra) & bindin $(S)$ & VE binding & $\mathrm{R}, \mathrm{P}, \mathrm{HP}, \mathrm{RE}, \mathrm{SD}, \mathrm{GI}$ & $\begin{array}{c}\text { (Metz et al., 1994; Metz and Palumbi, 1996; } \\
\text { Palumbi, 1999; Geyer and Palumbi, 2003; Geyer } \\
\text { and Palumbi, 2005) }\end{array}$ \\
\hline $\begin{array}{l}\text { sea urchins } \\
\text { (Strongylocentrotus) }\end{array}$ & bindin $(S)$ & VE binding & $\mathrm{R}, \mathrm{P}, \mathrm{GI}, \mathrm{HP}, \mathrm{DD}, \mathrm{SD}$ & $\begin{array}{l}\text { (Biermann, 1998; Levitan, 2002; Levitan and } \\
\quad \text { Ferrell, 2006; Levitan et al., 2007) }\end{array}$ \\
\hline $\begin{array}{l}\text { sea urchins } \\
\text { (Heliocidaris) }\end{array}$ & bindin (S) & VE binding & $\mathrm{R}, \mathrm{P}, \mathrm{Gl}$ & (Zigler et al., 2003) \\
\hline $\begin{array}{l}\text { sea urchins } \\
\text { (Strongylocentrotus) }\end{array}$ & EBR1 (E) & sperm binding & $R, L, M$ & (Kamei and Glabe, 2003) \\
\hline $\begin{array}{c}\text { sea urchins } \\
\text { (Strongylocentrotus) }\end{array}$ & $\begin{array}{l}\text { suREJ1, suREJ2, suREJ3 } \\
\text { (S) }\end{array}$ & $\begin{array}{l}\text { egg-jelly binding, unknown, acrosome reaction } \\
\text { signal transduction? }\end{array}$ & $\mathrm{R}, \mathrm{P}$ & (Mah et al., 2005) \\
\hline $\begin{array}{l}\text { abalones } \\
\text { (Haliotis) }\end{array}$ & lysin (S) & VE dissolution & $\mathrm{R}, \mathrm{P}, \mathrm{Gl}, \mathrm{M}, \mathrm{MA}$ & $\begin{array}{l}\text { (Lee and Vacquier, 1992; Lee et al., 1995; Lyon } \\
\text { and Vacquier, 1999; Yang et al., 2000; Yang and } \\
\text { Swanson, 2002) }\end{array}$ \\
\hline $\begin{array}{l}\text { abalones } \\
\text { (Haliotis) }\end{array}$ & sp18 (S) & sperm-egg cell membrane fusion? & $\mathrm{R}, \mathrm{P}$ & (Swanson and Vacquier, 1995) \\
\hline $\begin{array}{l}\text { abalones } \\
\text { (Haliotis) }\end{array}$ & VERL (E) & lysin-binding & $\mathrm{R}, \mathrm{P}$ & $\begin{array}{l}\text { (Swanson and Vacquier, 1998; Galindo et al., } \\
\text { 2003) }\end{array}$ \\
\hline $\begin{array}{l}\text { turban snails } \\
\text { (Tegula) }\end{array}$ & lysin (S) & VE dissolution & $R, P, M$ & (Hellberg and Vacquier, 1999) \\
\hline $\begin{array}{l}\text { turban snails } \\
\text { (Tegula) }\end{array}$ & TMAP (S) & unknown & $R, P, L$ & (Hellberg et al., 2000) \\
\hline mussels (Mytilus) & M7 lysin (S) & VE dissolution & $\mathrm{R}, \mathrm{P}, \mathrm{BA}^{1}, \mathrm{RE}^{2}$ & $\begin{array}{l}\text { (Riginos and McDonald, 2003; Riginos et al., } \\
\text { 2006) })^{1} \text { (Springer and Crespi, 2007) }\end{array}$ \\
\hline \multicolumn{5}{|l|}{ Insects } \\
\hline $\begin{array}{c}\text { fruit flies } \\
\text { (12 species from melanogaster and virilis } \\
\text { species groups) }\end{array}$ & $\begin{array}{l}\text { unidentified proteins from } \\
\text { ovary and testis }(\mathrm{M}, \mathrm{F})\end{array}$ & unknown & $\mathrm{R}$ & (Civetta and Singh, 1995) \\
\hline D. melanogaster and $D$. simulans & Acps (M) & $\begin{array}{l}\text { sperm competition, sperm storage, stimulates } \\
\text { ovulation in females, stimulates female immune } \\
\text { system, decreased longevity in females }\end{array}$ & $R, P, M A$ & $\begin{array}{c}\text { (reviewed in Panhuis et al., 2006; Ram and } \\
\text { Wolfner, 2007) }\end{array}$ \\
\hline D. pseudoobscura & Acp26Aa (aka ovulin) (M) & stimulates ovulation in females & $\mathrm{R}, \mathrm{P}$ & (Wagstaff and Begun, 2005a) \\
\hline D. pseudoobscura & Acps (M) & $\begin{array}{l}\text { sperm competition, sperm storage, stimulates } \\
\text { ovulation in females, stimulates female immune } \\
\text { system, decreased longevity in females }\end{array}$ & $R, P, L$ & (Schully and Hellberg, 2006) \\
\hline$D$. mojavensis and $D$. arizonae & $\begin{array}{l}\text { female reproductive tract } \\
\text { proteins }(F)\end{array}$ & proteases, unknown & $R, D, P$ & (Kelleher et al., 2007) \\
\hline field crickets (Gryllus) & seminal proteins $(\mathrm{M})$ & unknown & $\mathrm{R}, \mathrm{P}$ & (Andres et al., 2006) \\
\hline $\begin{array}{l}\text { ground crickets and field crickets } \\
\text { (Allonemobius, Gryllus) }\end{array}$ & seminal proteins $(M)$ & unknown & $\mathrm{R}, \mathrm{P}$ & (Braswell et al., 2006) \\
\hline \multicolumn{5}{|l|}{ Rodents } \\
\hline mice (Mus), rats (Rattus) & RHOX5 (aka PEM, M,F) t & $\begin{array}{l}\text { transcription factor, regulates testis and ovary genes } \\
\text { - affects sperm production, sperm motility, fertility }\end{array}$ & $\mathrm{R}, \mathrm{P}$ & (Sutton and Wilkinson, 1997; MacLean et al., 2005) \\
\hline mice (Mus) & ZP3 (E) & zona pellucida (ZP) structure, sperm binding & $\mathrm{R}, \mathrm{P}$ & (Jansa et al., 2003) \\
\hline mice $(M u s)$, murine rodents & CATSPER1 (S) & sperm motility & $R, P, L$ & \\
\hline Australasian murine rodents & ZP3 (E) & sperm binding & $\mathrm{R}, \mathrm{P}$ & (Swann et al., 2007) \\
\hline deer mice (Peromyscus) & ZP2, ZP3 (E) & ZP structure, sperm binding & $\mathrm{R}, \mathrm{P}$ & (Turner and Hoekstra, 2006) \\
\hline $\begin{array}{c}\text { pinyon mouse (I, Peromyscus true } I) \text { and } \\
\text { Osgood's mouse (P. gratus) }\end{array}$ & ZP3 (E) & ZP structure, sperm binding & $\mathrm{HP}, \mathrm{BS}$ & $\begin{array}{l}\text { (Turner and Hoekstra, 2008) } \\
\text { (Podlaha et al., 2005) }\end{array}$ \\
\hline deer mice (Peromyscus) & $\begin{array}{l}\text { LRRC50 (M); GM1276 (M); } \\
\text { ACR (S); DDC8 (M); GSG1 } \\
\qquad(\mathrm{M})\end{array}$ & $\begin{array}{c}\text { protein binding; receptor activity, signal } \\
\text { transduction; ZP binding, dispersal of acrosomal } \\
\text { contents; unknown; unknown }\end{array}$ & $\mathrm{R}, \mathrm{P}$ & (Turner et al., in press) \\
\hline \multicolumn{5}{|l|}{ Primates } \\
\hline humans and great apes & $\begin{array}{l}\text { PRM1 (S), PRM2 (S), TNP2 } \\
(\mathrm{M})\end{array}$ & DNA packaging in sperm & $\mathrm{R}, \mathrm{P}$ & (Wyckoff et al., 2000) \\
\hline great apes & SEMG1, SEMG2 (M) & copulatory plug formation & $R, L$ & (Jensen-Seaman and Li, 2003) \\
\hline $\begin{array}{c}\text { humans (I, Homo sapiens), chimpanzees } \\
\text { (I, Pan troglodytes), gorillas (I, Gorilla } \\
\text { gorilla) }\end{array}$ & SEMG1 (M) & copulatory plug formation & $\mathrm{R}, \mathrm{P}$ & (Kingan et al., 2003) \\
\hline humans (I), primates & zonadhesin (S) & ZP binding & $\mathrm{R}, \mathrm{P}, \mathrm{BS}$ & (Gasper and Swanson, 2006) \\
\hline humans (I), primates & PKDREJ (S) & ZP binding? & $\mathrm{R}, \mathrm{P}, \mathrm{BS}$ & (Hamm et al., 2007) \\
\hline humans (I), primates & ESX1 (M) & spermatogenesis & $\mathrm{R}, \mathrm{P}$ & (Wang and Zhang, 2007) \\
\hline humans (I), chimpanzee & NYD-SP12 (M) & spermatogenesis & $\mathrm{R}, \mathrm{P}, \mathrm{HP}$ & (Zhang et al., 2007) \\
\hline
\end{tabular}

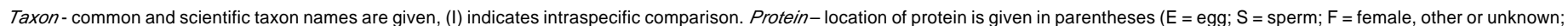

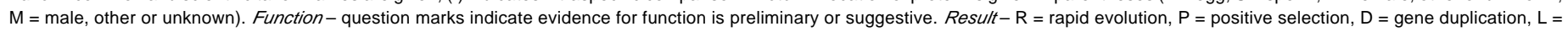

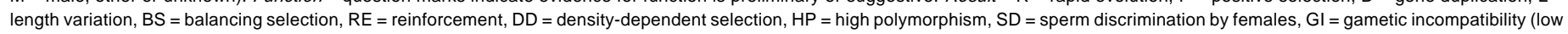

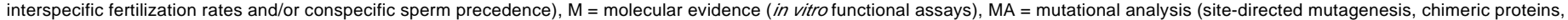
and/or deletions); superscripts indicate conflicting results and number corresponds to reference superscript. See also Herlyn and Zischler, 2008. 
species, though important in assessing the contribution of these proteins to speciation, have been lacking until recently.

Here we focus on recent advances in understanding reproductive protein evolution within and between closely related species. We first give a brief overview of the selective forces that may cause rapid reproductive protein evolution and discuss the potential contribution of reproductive proteins to speciation. We then review patterns of change observed in reproductive proteins across animals. Finally, focusing on mammals, we synthesize recent results, identify some common patterns, and suggest future directions. Throughout this review, we concentrate on the ways in which evolutionary and developmental approaches are complementary and how their integration is essential to a comprehensive understanding of fertilization.

\section{The causes of rapid reproductive protein evolution}

An obvious first question is why reproductive proteins evolve rapidly. Many evolutionary forces have been implicated, including pathogen resistance, sperm competition, cryptic female choice, sexual conflict, reinforcement, and avoidance of heterospecific fertilization. We describe these forces only briefly as they are explained more fully in previous reviews (Howard, 1999; Swanson and Vacquier, 2002a; Clark et al., 2006).

Selection can act on reproductive proteins at several points during fertilization. To achieve fertilization, sperm and eggs must come in contact with foreign molecules (the gametes of the opposite sex); this, along with necessary exposure to a novel environment (e.g., sperm traveling through the female reproductive tract) makes gametes vulnerable to attack from microbial pathogens. Egg and sperm proteins may thus be selected to evade and resist these attacks independently of any evolutionary forces promoting fertilization success. Selection can also act on gamete interactions themselves. First, selection may arise from interactions between conspecific individuals. In polyandrous species, in which a female mates with multiple males, females may discriminate between sperm from different males, exerting "cryptic choice". In addition, intrasexual competition between the sperm of different males to fertilize the egg can cause strong selection on sperm to rapidly penetrate and fertilize the egg. Females, however, may prefer a lower optimal rate of fertilization than males to reduce the risk of polyspermy. This difference between sexes in optimal fertilization rates can yield sexual conflict at the gamete level. This conflict may result in maintenance of polymorphism or an endless coevolutionary arms race between egg and sperm proteins (Palumbi, 1999; Gavrilets, 2000). Second, selection may arise from heterospecific interactions. If gametes from different species meet and hybrids have reduced fitness, selection will favor changes in protein interactions that reduce heterospecific fertilization, as this is a waste of reproductive effort. The various types of selection that can act on reproductive proteins are difficult to disentangle and may operate simultaneously in a single species (Coyne and Orr, 2004).

\section{The consequences of rapid reproductive protein evolu- tion}

The second question, on which we focus here, is: what are the consequences of reproductive protein evolution - do changes in reproductive proteins really matter for speciation?

In other words, do changes in the amino acid sequences of reproductive proteins contribute to the initial stages of reproductive isolation between diverging populations? This question is difficult to answer, and requires combining studies of variation in nature with functional molecular assays in the laboratory.

The critical element is one of timing; whenreproductive proteins change relative to other factors promoting divergence (e.g., ecological specialization) determines whether reproductive genes are important in incipient speciation. Specifically, we want to know if changes in reproductive proteins causespeciation, or if they simply accumulate after species have already diverged. Figure 1 depicts a simple model of speciation in which gametic incompatibility arises as a result of rapid evolution of gamete interaction proteins in two physically separated populations. In contrast, if reproductive protein divergence occurs after populations are completely reproductively isolated due to other mechanisms (e.g. mate choice, habitat preference, timing), it has no consequences for fertilization potential.

While many studies have begun to shed light on either the

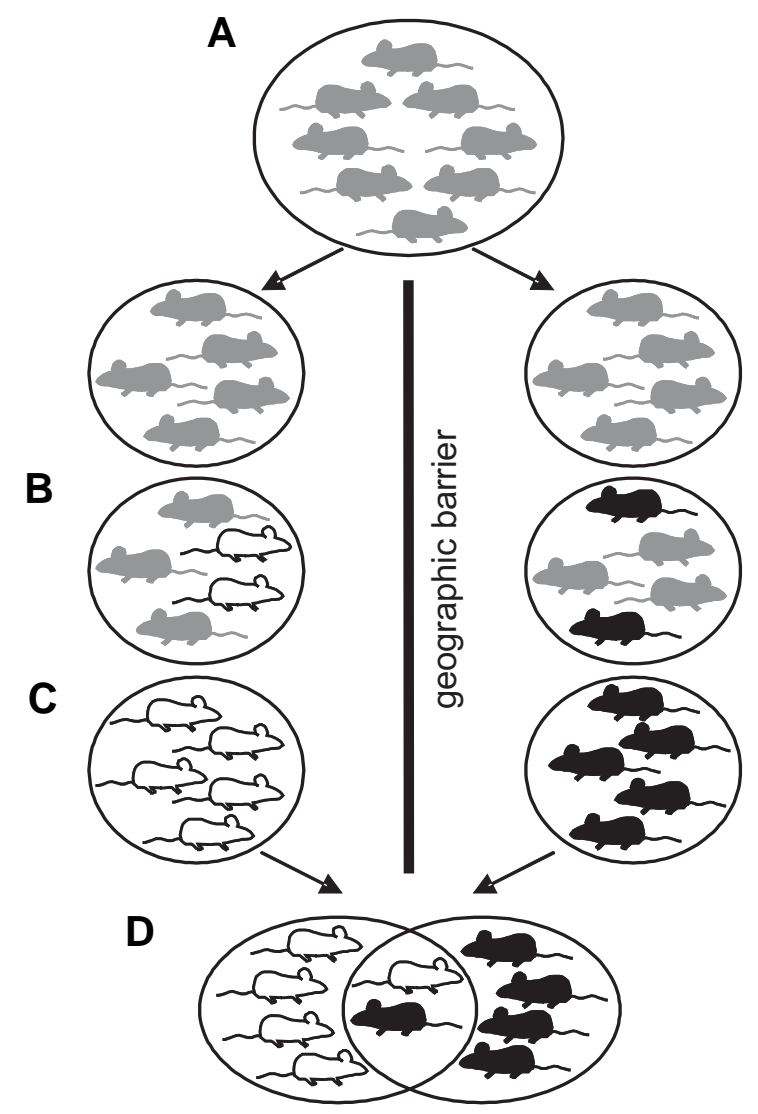

Fig. 1. A simple model of reproductive isolation arising from gametic incompatibility. (A) A single population splits into two by a geographic barrier. (B) A new sperm gene allele arises in one population (indicated in black) and a new egg gene allele arises in the other (indicated in white). (C) The new alleles replace the old alleles in each population. (D) The populations come into contact. When individuals from different populations mate, eggs and sperm are no longer compatible. This gametic incompatibility results in reproductive isolation between the populations (indicated by a solid line around each). 
evolutionary patterns of reproductive proteins or on the molecular mechanisms of fertilization, there are no systems in which the complete story has been told. We highlight below some of the most thorough studies, emphasizing how evolutionary and developmental approaches can inform one another to illuminate the causes and consequences of rapid reproductive protein evolution.

\section{Marine invertebrates}

The earliest studies of fertilization protein evolution involved marine invertebrates. These species have long been used as models for fertilization research because their gametes are copious and easily collected (Kresge et al., 2001). In addition, because fertilization occurs externally - gametes are simply released into the water - fertilization success is primarily mediated by gamete proteins. In contrast, internal fertilization involves complex interactions between many proteins present in the sperm and semen of males and the egg and reproductive tract of females. Consequently, selection can act on many different proteins and at many different times, even before mating, to control which individuals exchange gametes (e.g., selection on behaviors to avoid heterospecific fertilization or to choose the best mate). Thus, gamete proteins in externally fertilizing species are obvious targets of selection because they mediate a large portion of the fertilization process compared to internally fertilizing species. In fact, rapid evolution and positive selection of fertilization proteins have been documented in several taxa of marine invertebrates including abalones, sea urchins, turban snails, and mussels (Table 1). Here, we highlight studies in abalones and sea urchins in which the molecular function of gamete-interaction proteins and their potential role in reproductive isolation are particularly well understood.

\section{Gamete interaction in abalones}

The interaction of the gamete proteins lysin and VERL in abalones (genus Haliotis) is arguably the best characterized fertilization process in animals (reviewed in Kresge et al., 2001; Panhuis et al., 2006). The abalone fertilization process was first studied by developmental biologists in the lab. To fertilize an egg, an abalone sperm must pass through a layer of egg jelly until it reaches the vitelline envelope (VE). Contact with the VE stimulates release of the contents of the acrosome, which disassociates fibers of the VE and allows the sperm to pass through to the egg cytoplasmic membrane (Fig. 2A,B). Isolation of the contents of the acrosome revealed two major protein components. One of these was named "lysin" because of its ability to non-enzymatically dissolve, or lyse, the VE (Lewis et al., 1982). The egg protein that physically interacts with lysin was later identified and named VERL (vitelline envelope receptor for lysin; Swanson and Vacquier, 1997). VERL is a large glycoprotein composed of 22 tandem repeats, each of which binds a lysin dimer (Fig. 2E, Swanson and Vacquier, 1997; Galindo et al., 2002). Binding of lysin to VERL causes the molecules of VERL to disentangle, creating a hole in the VE through which the sperm can swim.

In abalones, egg-sperm binding appears species-specific. In vitro hybridization experiments have shown that optimal sperm concentrations are ten times higher and maximal fertilization rates much lower for heterospecific than for conspecific sperm (Leighton and Lewis, 1982). Moreover, dissolution of the VE by purified lysin and, to a lesser extent, in vitro binding of lysin and VERL, show the same species specificity as does egg-sperm binding (Swanson and Vacquier, 1997; Lyon and Vacquier, 1999), demonstrating that the interaction of these two proteins is the species-specific step of fertilization in abalones.

Comparison of amino acid sequences between closely related abalone species revealed that lysin evolves remarkably rapidly. Lysin is one of the rare molecules in which a strong signal of positive selection is observed: the amino acid substitution rate exceeds the synonymous substitution rate $\left(d_{N} / d_{S}>1\right.$; Lee and Vacquier, 1992; Lee et al., 1995; Nunney and Schuenzel, 2006). In fact, lysin is one of the most rapidly evolving proteins ever seen (Metz et al., 1998b). However, only the first two repeats of VERL are subject to positive selection (Fig. 2E), suggesting this part of the protein could be coevolving with lysin (Galindo et al., 2003). [In contrast, repeats 3-22 of VERL evolve neutrally; concerted evolution probably homogenizes most of these repeat sequences within a given species (Swanson and Vacquier 1998).] One possible scenario is that coevolution results from conflict over fertilization rate; VERL evolves to decrease sperm-binding rates and avoid polyspermy, while lysin is selected to increase binding speed in response, leading to an ongoing "coevolutionary chase" (Galindo et al., 2003). Why then does diversifying selection act on repeats 1-2 but not 3-22? One explanation is that lysin could have different binding affinities for different repeated regions of VERL. We know species specificity is strongest as VE dissolution is initiated (Swanson and Vacquier, 1997), so perhaps lysin binds in a species-specific manner to repeats 1 and 2, causing VERL molecules to begin to unravel, and then bind with less specificity to repeats 3-22 (Fig. 2F; Galindo et al., 2003).

Evolutionary analysis provided hints about which regions of lysin interact with VERL. Amino acid divergence varies between different regions of lysin - some are conserved between species while others are highly variable. The divergent regions are strong candidates for mediating species specificity of binding. Molecular analyses were used to test this hypothesis; variable regions of lysin from red abalone and pink abalone were exchanged via sitedirected mutagenesis to produce chimeric proteins (Fig. 2C; Lyon and Vacquier, 1999). Differences in the ability of these chimeric proteins to dissolve VEs from the two abalone species showed that the $\mathrm{N}$ - and $\mathrm{C}$-termini and one internal region are major determinants of species specificity (Fig. 2D). The crystal structure of lysin from two species of abalone has been determined, allowing visualization of the relative positions of these regions; the $\mathrm{N}$ - and C-termini are adjacent to each other on one side of the folded protein, suggesting that these two domains constitute the major site where lysin binds to VERL (Shaw et al., 1993; Shaw et al., 1995; Kresge et al., 2000a,b). This series of evolutionary and molecular studies clearly have shown that gamete proteins have the potential to play a prominent role in maintaining species boundaries in abalones.

\section{Bindin evolution in sea urchins}

Studies in sea urchins provide further insight into the evolutionary consequences of gametic interactions in external fertilizers. The egg-binding protein bindin has received the most attention, 
A

Fertilization in abalone

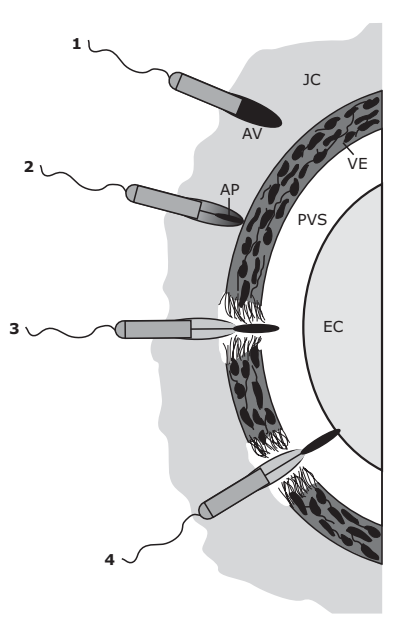

B

Lysin dissolves the vitelline envelope (VE)

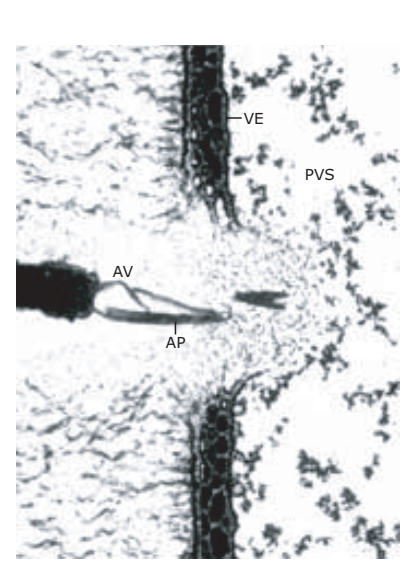

C Lysin

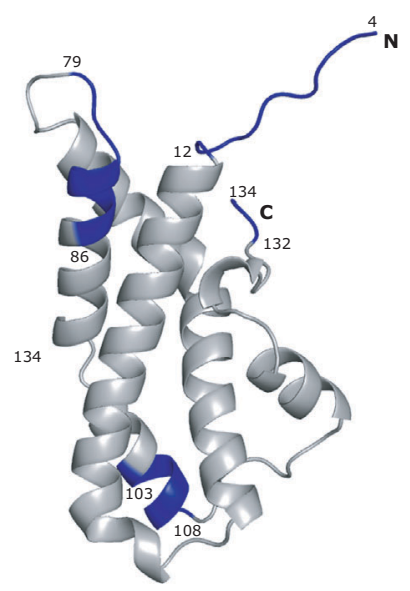

Chimeric lysin constructs
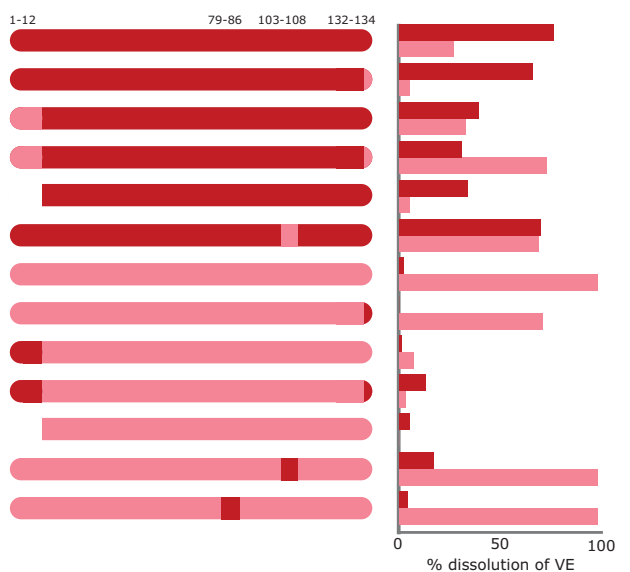

E VERL

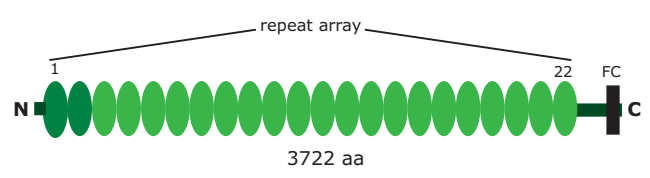

F Lysin-VERL interaction

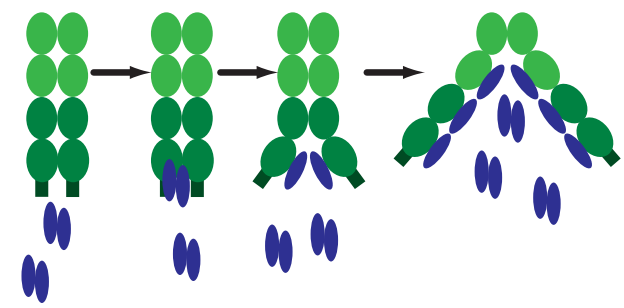

Fig. 2. Interaction of lysin and "vitelline envelope receptor for lysin" (VERL) during abalone fertilization. (A) Steps of fertilization in abalone (adapted from Kresge et al., 2001). (1) The sperm penetrates the egg jelly coat (JC). (2) The sperm comes into contact with the egg vitelline envelope (VE), which stimulates release of the contents of the acrosomal vesicle (AV) including lysin and elongation of the acrosomal process (AP). Lysin dissolves the VE, causing a hole to form. (3) The sperm passes through the hole in the VE into the perivitelline space (PVS). (4) The membrane of the acrosomal process fuses with the egg plasma membrane and the sperm enters the egg cytoplasm (EC). (B) Thin section transmission electron micrograph of a sperm dissolving a hole in the VE $(21,400 X$, used with permission from Lewis et al., 1982). (C) Structure of red abalone lysin; regions interchanged between species to produce chimeric proteins are in blue (adapted from Lyon and Vacquier, 1999). (D) Chimeric lysin constructs tested by Lyon and Vacquier (1999). Graph shows the percent dissolution of red (red bars) and pink (pink bars) abalone VEs by $20 \mu \mathrm{g}$ of protein after four minutes (adapted from Lyon and Vacquier, 1999). (E) VERL structure (adapted from Galindo et al., 2002); repeats subject to positive selection are in dark green, repeats evolving neutrally by concerted evolution are in light green; FC, furin cleavage site. (F) A model of the molecular interaction between lysin (blue) and VERL (green) (adapted from Kresge et al., 2001). A lysin dimer binds to a VERL repeat, disrupting hydrogen bonds between VERL molecules and causing lysin to monomerize. As the molecules separate, more repeats are accessible to lysin and the process continues, unraveling the VERL molecules. Binding of lysin to the first two repeats of VERL is predicted to be more species-specific than binding to repeats 3-22 (Galindo et al., 2003).

having been studied within and between several sea urchin species representing diverse genera (reviewed in Zigler et al., 2005; see article by Zigler in this issue). Like abalone lysin, bindin diverges rapidly between species and shows strong evidence for positive selection in many (Zigler et al., 2005) but not all genera (e.g. Metz et al., 1998a; Zigler and Lessios, 2003, 2004). Comparative analyses suggest that amino acid changes in bindin may play an important role in reproductive isolation in sea urchins; divergence at nonsynonymous sites in bindin correlates with gametic incompatibility, while divergence at synonymous sites and in a mitochondrial gene does not (Zigler etal., 2005). Detailed intraspecific analyses and geographic studies of allelic variation suggest that in some, but not all species, divergence was promoted by selection against hybridization (reinforcement; Geyer and Palumbi, 2003; McCartney and Lessios, 2004). However, evolutionary forces are likely to be complex; comparisons of reproductive success among individuals in one natural population of sea urchins (Strongylocentrotus franciscanus) showed that success of a particular bindin genotype depends on sex, genotype frequency, and sperm density (Levitan and Ferrell, 2006). Such studies have focused on the causes of rapid bindin divergence, but the detailed functional analyses necessary to molecu- 
larly characterize the precise consequences of amino acid change on fertilization potential are awaited.

So far, research on the evolution of egg-sperm binding in sea urchins has focused solely on bindin. The egg receptor for bindin (EBR1) recently has been identified and sequenced in two species (Kamei and Glabe, 2003), and as in lysin and VERL, evolutionary analyses of bindin and EBR 1 may help characterize their molecular interaction. What is perhaps most exciting is the opportunity to compare male-female pairs with known genotypes (at both sperm protein and egg receptor genes), which may help identify the precise molecular causes of variation in fertilization success in nature.

\section{Insects}

While gamete proteins have been the focus of study in marine invertebrates, egg-sperm binding proteins have yet to be identified in insects. Perhaps the best-studied group of reproductive proteins comprises the proteins produced by the accessory glands of male Drosophila (Acps). Here we give just a brief overview of Acp evolution, as this has been reviewed previously (Swanson and Vacquier, 2002b; Panhuis et al., 2006; Ram and Wolfner, 2007).

More than 100 Acps have been identified in D. melanogaster (Ram and Wolfner, 2007). Acps influence female behavior and physiology, affecting storage and use of sperm, oviposition rates, and remating rates. While most of these effects increase the reproductive success of males, they are harmful to females, decreasing their longevity (Ram and Wolfner, 2007). Consequently, sexual conflict may be an important force driving Acp evolution (reviewed in Panhuis et al., 2006; Ram and Wolfner, 2007). In fact, Acp genes evolve twice as fast as non-Acp genes in comparisons of $D$. melanogaster with its sibling species $D$. simulans (Swanson et al., 2001a), and many of these Acp genes show a signature of positive selection (Ram and Wolfner, 2007). Comparison of $D$. mojavensis and $D$. arizonaesuggests that Acps evolve even faster among these more promiscuous species (Wagstaff and Begun, 2005b).

Recently, female proteins that may interact with male Acps have been identified (Lawniczak and Begun, 2004; Swanson et al., 2004; Kelleher et al., 2007). Many of these candidate female proteins also show evidence for positive selection (Swanson et al., 2004; Panhuis and Swanson, 2006; Lawniczak and Begun, 2007) and, as with Acps, evolve faster in more promiscuous groups (Kelleher et al., 2007).

Evolutionary-genomic approaches have identified many rapidly evolving male and female proteins that probably interact and coevolve. For several Acps, knockout experiments have characterized their effects on female fitness (Ram and Wolfner, 2007). As a next step, evolutionary data can guide molecular experiments to identify and characterize Acp-female protein interaction pairs and their role in fertilization. For example, in vitro assays may be used to test the interaction between Acps and proteases present in the female reproductive tract (Lawniczak and Begun, 2004; Swanson et al., 2004; Kelleher et al., 2007); these experiments could test the specific hypothesis that female proteases degrade male Acps.

Male reproductive proteins have also been identified in honeybees, mosquitoes and crickets (Andres et al., 2006; Braswell et al., 2006; Collins et al., 2006; Davies and Chapman, 2006; Dottorini et al., 2007). In crickets there is evidence for positive selection on male seminal proteins, suggesting that adaptive evolution of these proteins may be common although additional taxa must be surveyed. Knowledge of the identity and evolution of other reproductive proteins, such as egg-sperm interaction proteins, is lacking in insects. Although recent large-scale studies using proteomic (Dorus et al., 2006) and comparative genomic (Haerty et al., 2007) approaches have begun to identify additional rapidly evolving male reproductive proteins in Drosophila. While these studies represent a first step, functional studies of these proteins are required to understand their contribution, if any, to reproductive isolation.

\section{Vertebrates}

Research on vertebrates shows that adaptive evolution of gamete proteins is not limited to externally fertilized taxa. Among vertebrates, knowledge of reproductive protein evolution is limited primarily to mammals (but see Berlin and Smith, 2005), but has been broad in scope, including proteins involved in many

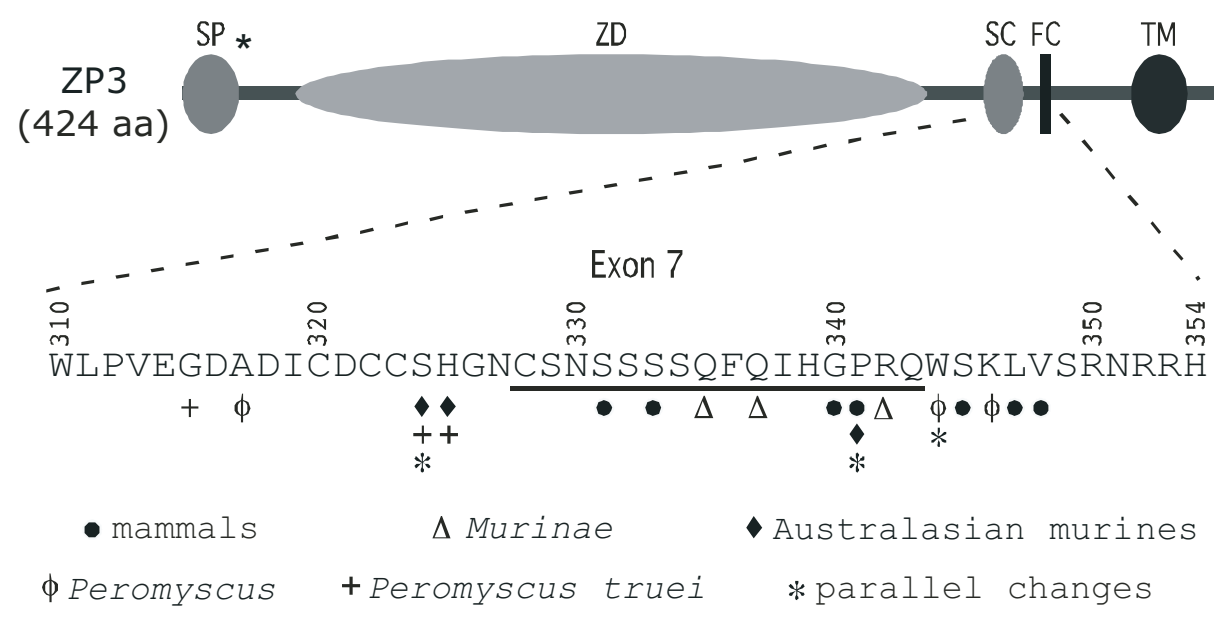

Fig. 3. Adaptive evolution of ZP3 in mammals. The Mus musculus amino acid sequence for exon 7 is shown; the sperm-combining region (following Kinloch et al., 1995) is underlined. Sites subject to positive selection in studies of diverse mammals (Swanson et al., 2001b), Mus (Jansa et al., 2003), Australasian rodents (Swann et al., 2007), and Peromyscus (Turner and Hoekstra, 2006), as well as variable sites in Peromyscus truei (Turner and Hoekstra, 2008) are indicated. Sites with parallel amino acid substitutions are highlighted. The structure of ZP3 is shown above; $S P$, signal peptide; $Z D$, zona domain; $S C$, spermcombining region; $F C$, furin cleavage site; $T M$, transmembrane domain. Star indicates an additional cluster of positively selected sites in exon 1 identified in studies of diverse mammals (Swanson et al., 2001b) and rodents (Jansa et al., 2003). 
stages of fertilization (reviewed in Clark et al., 2006) and at different levels of taxonomic divergence. Genomic approaches have documented high evolutionary rates of sperm proteins (Torgerson etal., 2002), seminal fluid proteins (Clark and Swanson, 2005), proteins expressed during spermatogenesis (Good and Nachman, 2005), and proteins having testis-specific expression (Turner et al., in press). All of these genomic studies provide evidence for positive selection (Table 1). Studies of candidate genes, chosen because they play a role in fertilization, also have identified several targets of selection (Table 1; Singh and Kulathinal, 2000; Swanson and Vacquier, 2002b; Clark et al., 2006). Taken together, these data show that selection acts on a functionally diverse set of mammalian reproductive proteins.

Until recently, research on reproductive protein evolution in mammals involved comparing sequences among only distantly related species. However, processes occurring within species and among closely related species are more relevant to understanding how amino acid changes affect fertilization and ultimately reproductive isolation. New and interesting patterns are emerging as more data become available about the evolution of reproductive proteins on shorter timescales. Here, we first describe in detail the evolution of the egg protein ZP3, in which several of these patterns are evident, then relate these findings to data from other mammalian reproductive proteins.

\section{Evolution of ZP3 in mammals}

Zona pellucida glycoprotein 3 (ZP3) is one of the best-characterized mammalian fertilization proteins, from both a functional and evolutionary perspective. ZP3 is one of three or four proteins that make up the zona pellucida, or egg coat, in mammals. ZP3 has been implicated in sperm binding in the mouse, although there are contradictory data from in vitro binding assays and transgenic experiments on the specific role of ZP3 (Rankin et al., 1998; Wassarman, 1999; Rankin et al., 2003). As a result, two models of sperm-ZP binding have been proposed. The first posits that ZP3 is the primary sperm receptor, binding sperm in a species-specific manner (reviewed in Wassarman, 1999). The alternative model proposes that sperm do not bind to only ZP3, but instead recognize the supramolecular structure of the zona pellucida (Dean, 2004). Further, ZP3 is a glycoprotein and its attached carbohydrates may also affect sperm binding (Clark and Dell, 2006). Additional evidence is required to resolve these conflicts, but a critical role for ZP3 in sperm binding in the mouse is unequivocal. ZP-sperm binding in other mammals is not as well characterized, but there are clearly taxonomic differences in the way that ZP proteins interact with sperm (Sinowatz et al., 2001; Nixon et al., 2007).

ZP3 was one of the first fertilization proteins that showed evidence for positive selection in mammals (Swanson et al., 2001b). This early study aligned DNA sequences from eight phylogenetically diverse mammals and identified several amino acid sites as targets of selection. These target sites are clustered in two regions of ZP3. The first cluster lies in an $\mathrm{N}$-terminal region with unknown function and the second lies in and around a region described as the "sperm-combining" region (Fig. 3; Kinloch et al., 1995; Swanson et al., 2001b; but see Berlin and Smith, 2005).

More recently, several studies have documented adaptive evolution of ZP3, in particular the sperm-combining region, in rodents (Mus, Jansa et al., 2003; Peromyscus, Turner and Hoekstra, 2006; Australasian rodents, Swann etal., 2007). Taken together, results from these studies make a compelling case for adaptive evolution of the sperm-combining region (encoded by exon 7) of ZP3. First, amino acid sites identified as targets of selection in these studies are clustered together in and around the sperm-combining region (Fig. 3). In many cases, these sites are adjacent or even identical in comparisons among species. Second, within groups and even between more distant lineages, in which the starting amino acid sometimes differs, substitution to the same amino acid has occurred independently (e.g., X324I, X341A, W344R; Fig. 3). These sites with convergent change are of particular interest because they may affect ZP3-sperm interaction. Characterizing the functional effects of substitutions at these sites (and others) will help us understand the molecular mechanisms governing ZP-sperm binding in rodents.

At least in one group, amino acid polymorphism in the spermcombining region within several species has been found (Turner and Hoekstra, 2006). A more detailed study of ZP3 in Peromyscus trueishowed that divergent alleles of ZP3 are present at similar frequencies in geographically distant populations, a result consistent with balancing selection maintaining ZP3 variation in this species (Turner and Hoekstra, 2008), although additional studies are needed to rule out other selective and demographic scenarios.

Thus far, several studies of ZP3 evolution have found evidence for positive selection, and amino acid changes in the region putatively important for egg-sperm binding. But has ZP3 evolution played any role in reproductive isolation? Within the genus Mus, none of the variable sites near the sperm-combining region differ between sister species (Jansa et al., 2003). Similarly, divergence among closely related species of Australasian rodents is low (Swann et al., 2007). In contrast, there is extensive amino acid sequence variation in ZP3 within and among closely related species in Peromyscus (Turner and Hoekstra, 2006). It is possible, however, that one or few changes in the sperm-combining region could drastically affect ZP3-sperm binding. Functional assays to test the affects of ZP3 allelic variation on egg-sperm binding and fertilization success are needed.

\section{Other fertilization proteins in mammals}

Characterizing evolutionary patterns in a small but functionally diverse set of reproductive proteins has identified new targets of selection in the mammalian fertilization process. In females, several proteins show evidence for positive selection among recently diverged species. For example, ZP2 is another major protein component of the egg coat and has sperm-binding activity, although its function is not well characterized (Wassarman et al., 1999). ZP2 evolves adaptively and has several parallel amino acid substitutions among species of Peromyscus (Turner and Hoekstra, 2006).

On the male side, elevated rates of adaptive amino acid substitution in groups of closely related species have been reported for proteins involved in different stages of sperm production and function. For example, RHOX5 (also called PEM), a homeobox transcription factor expressed only in reproductive tissue, is required for normal sperm production, morphology, and motility in mice (MacLean et al., 2005). In rodents, RHOX5 


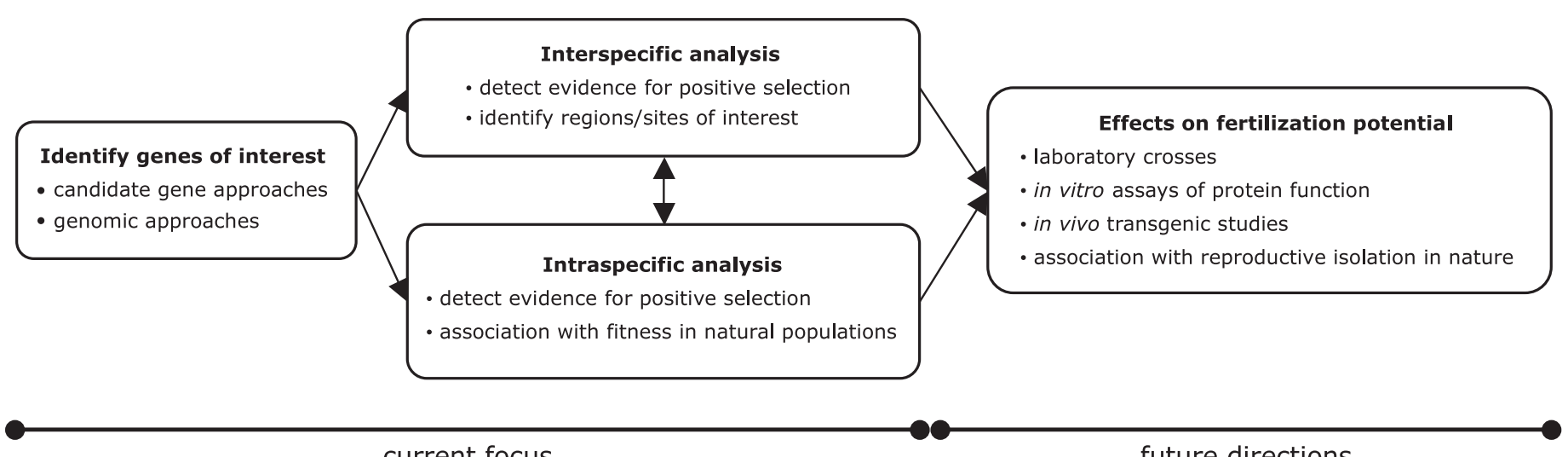

current focus

future directions

Fig. 4. Common approaches and new directions in the study of reproductive protein evolution.

evolves rapidly and is subject to positive selection (Sutton and Wilkinson, 1997), a particularly surprising result since homeodomains are generally highly conserved. Protamines, the sperm-specific DNA packaging proteins that are members of the generally conserved DNA-binding protein class, evolve rapidly in primates (Retief et al., 1993; but see Clark and Civetta, 2000). Intriguingly, the rate of protamine evolution is positively correlated with the degree of promiscuity (and thus sperm competition) in primates (Wyckoff et al., 2000).

Protein length as well as composition can vary adaptively among closely related species. Length variation in the sperm motility protein CATSPER1 in rodents (Podlaha et al., 2005) and the seminal plug proteins SEMG1 and SEMG2 in primates (JensenSeaman and Li, 2003; Kingan et al., 2003) is subject to positive selection. As in protamines, SEMG1/SEMG2 evolution is positively correlated with promiscuity (Jensen-Seaman and Li, 2003; Kingan et al., 2003; Dorus et al., 2004).

There have been surprisingly few intraspecific studies of reproductive proteins in mammals. To our knowledge, data are limited to five male reproductive proteins in primates and one study of ZP3 in Peromyscus truei (Turner and Hoekstra, 2008). ESX1, another homeobox transcription factor active during spermatogenesis, shows significant evidence of recent selective sweeps in humans and rapid adaptive amino acid substitution among a diverse sample of primates (Wang and Zhang, 2007). SEMG2, one of the seminal plug proteins described above, shows signs of selective sweeps in both chimps and humans (Kingan et al., 2003). Like ZP3 in P. truei, the other three male proteins have high levels of intraspecific amino acid variation. NYD-SP12 is a protein involved in acrosome formation during spermatogenesis that shows significant signs of positive selection among primates, particularly along the chimp and human lineages (Zhang et al., 2007).

Evidence for adaptive evolution of two candidate egg-binding sperm proteins, PKDREJ and zonadhesin, has been reported in primates and humans (Gasper and Swanson, 2006; Hamm et al., 2007; Herlyn and Zischler, 2008). In both cases, there is evidence for balancing selection maintaining amino acid polymorphisms. Interestingly, sites that are polymorphic within humans are found in the same regions as sites that are positively selected across primates. These adaptively evolving regions include both domains implicated in ZP-binding and domains without known functions. In contrast to patterns in protamines and seminal plug proteins, there is no evidence that rates of evolution of these eggbinding proteins correlate with the degree of sperm competition. Evidence for adaptive sequence variation in these proteins among humans raises the possibility that these proteins may contribute to variation in fertility among individuals, although associations between allelic variation and fertilization success have not been tested. Data on patterns of intraspecific variation of egg coat proteins in humans may show whether egg-sperm binding pairs are coevolving, a finding that could help identify the causes of infertility in couples.

These studies of reproductive protein evolution in mammals suggest some general conclusions. First, many reproductive proteins diverge rapidly among closely related mammals, raising the possibility that change in these proteins contribute to reproductive isolation, although functional tests of natural variation are awaited. Second, studies in diverse species suggest that the same proteins, and even the same amino acid sites, have been repeatedly targeted by selection. Finally, amino acid polymorphism within species has been reported for several fertilization proteins, raising the possibility that gametes interact differently and contribute to variation in fertility among individuals of a species. However, such intraspecific data are scarce - our conclusions are based on just a handful of proteins in only two mammalian groups, rodents and primates.

\section{The nexus of evolution and development}

Tremendous advances in understanding both the mechanics and evolution of fertilization will be possible with the integration of developmental and evolutionary biology. To achieve this, evolutionary biologists must go beyond the statistical analysis of protein evolution, and developmental biologists must go beyond studying single strains within species.

Many evolutionary biologists have a standard procedure for studying selection from DNA or protein sequences (Fig. 4). First, candidate genes are identified and sequenced in several taxa. Next, statistical tests are used to determine if the genes are evolving adaptively and, if so, to identify the specific sites subject to selection. These tests have been criticized because they can detect selection only when adaptation has occurred via multiple amino acid substitutions in a single protein (Hughes, 2007). 
However, rapid divergence of reproductive proteins is not rare, as we have seen, particularly among proteins mediating interactions between male and female gametes. Certainly tests for positive selection based on nucleotide sequence data will miss important cases of adaptation. Nevertheless, these tests have been successful at identifying functionally important regions of proteins in the absence of any a priori information that these regions were important (e.g., Lyon and Vacquier, 1999; Yang, 2005). Despite these limitations, these are currently the best tests available for identifying candidate sites affecting protein function.

While such comparative studies can identify interesting genes and gene regions, they reveal little about the functional effects of evolutionary change on fertilization potential, which cannot be reached through statistical inference alone. An integrative approach, combining evolutionary analyses of natural populations, traditional genetics, and, most important, tests of molecular function, is required to determine the consequences of change in reproductive proteins for fertility and species divergence.

Fertilization is a difficult process to study mechanistically - it requires the interaction of cells and proteins from two individuals and gametes are not amenable to cell culture. Nevertheless, many new molecular tools are available to help the evolutionary biologist study the actual effects of protein variation on fertilization potential. For example, the effects of amino acid changes at positively selected sites could be tested using site-directed mutagenesis and in vitro binding assays (e.g., Kinloch et al., 1995; Chen etal., 1998; Hickox et al., 2001; Williams et al., 2003, 2006). Alternatively, manipulation of genes could be performed in vivo using transgenics or targeted gene transfer (Flotte, 2007; Gao et al., 2007; Waehler et al., 2007).

Evolutionary biologists readily adopted genomic tools, such as microarrays and high through-put genotyping, however gene manipulation techniques, experiments in cell culture, in vitro protein assays and in vivotransgenic approaches have not been adopted for the wholesale study of evolutionary questions. The effects on protein function of evolutionary changes in protein sequence, then, have been neglected (Dean and Thornton, 2007). This is particularly important in studying speciation, for which divergence of gamete interactions could be an important source of reproductive isolation. We want to know whether divergence in protein sequence has led to gametic isolation, and there is no way to understand this without functional analysis. Clearly, this is one of the most fruitful areas of inquiry in which evolution and development intersect.

Developmental biologists often study fertilization in inbred lines, and have either neglected genetic variation as an annoyance, or as a source of experimental error. Yet this very variation can inform the study of the mechanics of fertilization. Evolutionary studies, for example, have shown that natural variation among individuals in fertilization proteins is common, is sometimes maintained by natural selection, and can have dramatic effects on fertilization success. Further, while laboratory experiments are often designed to minimize environmental variation, studies of natural populations have shown that fertilization success varies depending on the environment where gametes interact (e.g., high versus low sperm density).

Variation among species, especially those that are closely related, also can inform many developmental studies. Interspecific comparison of DNA sequences, for example, can identify not only novel reproductive proteins, but also proteins and protein regions likely to play important roles in fertilization. Such comparative sequence analyses will only get easier and faster as more genomes become available. Furthermore, a comparative approach at a functional level can also inform the study of fertilization. For example, comparing functional data across several species will determine the generalities of the fertilization process as well as elucidate the mechanisms that, in some cases, cause the binding of egg and sperm to be species-specific.

In summary, the time is ripe for the cross-fertilization of developmental and evolutionary biology. Evolutionary biologists can use the developmental methodologies of in vitro and in vivo gene manipulation techniques to test the molecular effects of protein substitution, and developmental biologists can take advantage of naturally occurring genetic variation to identify novel proteins and candidate protein regions that play important roles in fertilization. This integrated approach will help answer longstanding questions about fertilization and the origin and preservation of species.

\section{Acknowledgements}

The authors thank P. Wassarman and V. Vacquier for editing this issue and inviting us to contribute. We thank members of the Hoekstra laboratory, J. Coyne, and V. Vacquier for useful discussion and comments on the manuscript. Research on reproductive protein evolution in the Hoekstra lab was supported by a Howard Hughes Medical Institute Predoctoral Fellowship (to LMT), and a National Science Foundation doctoral dissertation improvement grant (DEB 0608030, to LMT and HEH).

\section{References}

ADHAM, I.M., NAYERNIA, K. and ENGEL, W. (1997). Spermatozoa lacking acrosin protein show delayed fertilization. Mol. Reprod. Dev. 46: 370-376.

ANDRES, J.A., MAROJA, L.S., BOGDANOWICZ, S.M., SWANSON, W.J. and HARRISON, R.G. (2006). Molecular evolution of seminal proteins in field crickets. Mol. Biol. Evol. 23: 1574-84.

BABA, T., AZUMA, S., KASHIWABARA, S. and TOYODA, Y. (1994). Sperm from mice carrying a targeted mutation of the acrosin gene can penetrate the oocyte zona-pellucida and effect fertilization. J. Biol. Chem. 269: 31845-31849.

BERLIN, S. and SMITH, N.G.C. (2005). Testing for adaptive evolution of the female reproductive protein ZPC in mammals, birds and fishes reveals problems with the M7-M8 likelihood ratio test. BMC Evolutionary Biology 5: 65.

BIERMANN, C.H. (1998). The molecular evolution of sperm bindin in six species of sea urchins (Echinoida: Strongylocentrotidae). Mol. Biol. Evol. 15: 1761-1771.

BRASWELL, W.E., ANDRES, J.A., MAROJA, L.S., HARRISON, R.G., HOWARD, D.J. and SWANSON, W.J. (2006). Identification and comparative analysis of accessory gland proteins in Orthoptera. Genome 49: 1069-80.

CHEN, J., LITSCHER, E.S. and WASSARMAN, P.M. (1998). Inactivation of the mouse sperm receptor, $\mathrm{mZP} 3$, by site-directed mutagenesis of individual serine residues located at the combining site for sperm. Proc. Natl. Acad. Sci. USA95: 6193-6197.

CIVETTA, A. and SINGH, R.S. (1995). High divergence of reproductive tract proteins and their association with postzygotic reproductive isolation in Drosophila melanogasterand Drosophila virilis group species. J. Mol. Evol. 41: 10851095.

CLARK, A.G. and CIVETTA, A. (2000). Evolutionary biology: Protamine Wars. Nature 403: 261-263.

CLARK, G.F. and DELL, A. (2006). Molecular models for murine sperm-egg binding. J. Biol. Chem. 281: 13853-13856.

CLARK, N.L., AAGAARD, J.E. and SWANSON, W.J. (2006). Evolution of reproductive proteins from animals and plants. Reproduction 131: 11-22.

CLARK, N.L. and SWANSON, W.J. (2005). Pervasive adaptive evolution in primate seminal proteins. PLoS Genet. 1: 335 - 342. 
COLLINS, A.M., CAPERNA, T.J., WILLIAMS, V., GARRETT, W.M. and EVANS, J.D. (2006). Proteomic analyses of male contributions to honey bee sperm storage and mating. Insect Mol. Biol. 15: 541-549.

COYNE, J.A. and ORR, H.A. (2004). Speciation. Sinauer Associates, Sunderland, Mass.

DAVIES, S.J. and CHAPMAN, T. (2006). Identification of genes expressed in the accessory glands of male Mediterranean fruit flies (Ceratitis capitata). Insect Biochem. Mol. Biol. 36: 846-856.

DEAN, A.M. and THORNTON, J.W. (2007). Mechanistic approaches to the study of evolution: The functional synthesis. Nat. Rev. Genet. 8: 675-688.

DEAN, J. (2004). Reassessing the molecular biology of sperm-egg recognition with mouse genetics. Bioessays 26: 29-38.

DORUS, S., BUSBY, S.A., GERIKE, U., SHABANOWITZ, J., HUNT, D.F. and KARR, T.L. (2006). Genomic and functional evolution of the Drosophila melanogaster sperm proteome. Nat. Genet. 38: 1440-1445.

DORUS, S., EVANS, P.D., WYCKOFF, G.J., CHOI, S.S. and LAHN, B.T. (2004). Rate of molecular evolution of the seminal protein gene SEMG2correlates with levels of female promiscuity. Nat. Genet. 36: 1326-1329.

DOTTORINI, T., NICOLAIDES, L., RANSON, H., ROGERS, D.W., CRISANTI, A. and CATTERUCCIA, F. (2007). A genome-wide analysis in Anopheles gambiae mosquitoes reveals 46 male accessory gland genes, possible modulators of female behavior. Proc. Natl. Acad. Sci. USA 104: 16215-16220.

FLOTTE, T.R. (2007). Gene therapy: The first two decades and the current stateof-the-art. J. Cell. Physiol. 213: 301-305.

GALINDO, B.E., MOY, G.W., SWANSON, W.J. and VACQUIER, V.D. (2002). Fulllength sequence of $\mathrm{VERL}$, the egg vitelline envelope receptor for abalone sperm lysin. Gene 288: 111-117.

GALINDO, B.E., VACQUIER, V.D. and SWANSON, W.J. (2003). Positive selection in the egg receptor for abalone sperm lysin. Proc. Natl. Acad. Sci. USA 100: 4639-43.

GAO, X., KIM, K.S. and LIU, D.X. (2007). Nonviral gene delivery: What we know and what is next. Aaps Journa/9: E92-E104.

GASPER, J. and SWANSON, W.J. (2006). Molecular population genetics of the gene encoding the human fertilization protein zonadhesin reveals rapid adaptive evolution. Am. J. Hum. Genet. 79: 820-830.

GAVRILETS, S. (2000). Rapid evolution of reproductive barriers driven by sexual conflict. Nature 403: 886-9.

GEYER, L.B. and PALUMBI, S.R. (2003). Reproductive character displacement and the genetics of gamete recognition in tropical sea urchins. Evolution 57: 1049-1060.

GEYER, L.B. and PALUMBI, S.R. (2005). Conspecific sperm precedence in two species of tropical sea urchins. Evolution 59: 97-105.

GOOD, J.M. and NACHMAN, M.W. (2005). Rates of protein evolution are positively correlated with developmental timing of expression during mouse spermatogenesis. Mol. Biol. Evol. 22: 1044-1052.

HAMM, D., MAUTZ, B.S., WOLFNER, M.F., AQUADRO, C.F. and SWANSON, W.J. (2007). Evidence of amino acid diversity-enhancing selection within humans and among primates at the candidate sperm-receptor gene PKDREJ. Am. J. Hum. Genet. 81: 44 - 52.

HELLBERG, M.E., MOY, G.W. and VACQUIER, V.D. (2000). Positive selection and propeptide repeats promote rapid interspecific divergence of a gastropod sperm protein. Mol. Biol. Evol. 17: 458-466.

HELLBERG, M.E. and VACQUIER, V.D. (1999). Rapid evolution of fertilization selectivity and lysin cDNA sequences in teguline gastropods. Mol. Biol. Evol. 16: 839-848.

HERLYN, H. and ZISCHLER, H. (2008). The molecular evolution of sperm zonadhesin. Int. J. Dev. Biol. 52: 781-790.

HICKOX, J.R., BI, M. and HARDY, D.M. (2001). Heterogeneous processing and zona pellucida binding activity of pig zonadhesin. J. Biol. Chem. 276: 41502 41509.

HOSEMANN, K.E., COLOSIMO, P.E., SUMMERS, B.R. and KINGSLEY, D.M. (2004). A simple and efficient microinjection protocol for making transgenic sticklebacks. Behaviour 141: 1345-1355.

HOWARD, D.J. (1999). Conspecific sperm and pollen precedence and speciation. Annu. Rev. Ecol. Syst.109-132.
HUGHES, A.L. (2007). Looking for Darwin in all the wrong places: the misguided quest for positive selection at the nucleotide sequence level. Heredity 99: 364-373.

JANSA, S.A., LUNDRIGAN, B.L. and TUCKER, P.K. (2003). Tests for positive selection on immune and reproductive genes in closely related species of the murine genus Mus. J. Mol. Evol. 56: 294-307.

JENSEN-SEAMAN, M. and LI, W.-H. (2003). Evolution of the Hominoid semenogelin genes, the major proteins of ejaculated semen. J. Mol. Evol. 57: 261.

KAMEI, N. and GLABE, C.G. (2003). The species-specific egg receptor for sea urchin sperm adhesion is EBR1, a novel ADAMTS protein. Genes \& Development 17: 2502-2507.

KELLEHER, E.S., SWANSON, W.J. and MARKOW, T.A. (2007). Gene duplication and adaptive evolution of digestive proteases in Drosophila arizonae female reproductive tracts. PLoS Genet. 3: e148.

KINGAN, S.B., TATAR, M. and RAND, D.M. (2003). Reduced polymorphism in the chimpanzee semen coagulating protein, semenogelin I. J. Mol. Evol. 57: 159169.

KINLOCH, R.A., SAKAI, Y. and WASSARMAN, P.M. (1995). Mapping the mouse ZP3 combining site for sperm by exon swapping and site-directed mutagenesis. Proc. Natl. Acad. Sci. USA 92: 263-267.

KRESGE, N., VACQUIER, V.D. and STOUT, C.D. (2000a). 1.35 and 2.07 angstrom resolution structures of the red abalone sperm lysin monomer and dimer reveal features involved in receptor binding. Acta. Crystallogr. D56: 34-41.

KRESGE, N., VACQUIER, V.D. and STOUT, C.D. (2000b). The high resolution crystal structure of green abalone sperm lysin: Implications for species-specific binding of the egg receptor. J. Mol. Biol. 296: 1225-1234.

KRESGE, N., VACQUIER, V.D. and STOUT, C.D. (2001). Abalone lysin: the dissolving and evolving sperm protein. Bioessays 23: 95-103.

LAWNICZAK, M.K.N. and BEGUN, D.J. (2004). A genome-wide analysis of courting and mating responses in Drosophila melanogaster females. Genome 47: 900-910.

LAWNICZAK, M.K.N. and BEGUN, D.J. (2007). Molecular population genetics of female-expressed mating-induced serine proteases in Drosophila melanogaster. Mol. Biol. Evol. 24: 1944-1951.

LEE, Y. and VACQUIER, V.D. (1992). The divergence of species-specific abalone sperm lysins is promoted by positive Darwinian selection. Biol. Bull. 182: 97104.

LEE, Y.H., OTA, T. and VACQUIER, V.D. (1995). Positive selection is a general phenomenon in the evolution of abalone sperm lysin. Mol. Biol. Evol. 12: 231238.

LEIGHTON, D.L. and LEWIS, C.A. (1982). Experimental hybridization in abalones. Int. J. Inver. Rep. Dev. 5: 273-282.

LESSIOS, H.A. and CUNNINGHAM, C.W. (1990). Gametic incompatibility between species of the sea-urchin Echinometra on the 2 sides of the Isthmus of Panama. Evolution 44: 933-941.

LEVITAN, D.R. (2002). The relationship between conspecific fertilization success and reproductive isolation among three congeneric sea urchins. Evolution 56 : 1599-1609.

LEVITAN, D.R. and FERRELL, D.L. (2006). Selection on gamete recognition proteins depends on sex, density, and genotype frequency. Science 312: 267269.

LEVITAN, D.R., TERHORST, C.P. and FOGARTY, N.D. (2007). The risk of polyspermy in three congeneric sea urchins and its implications for gametic incompatibility and reproductive isolation. Evolution 61: 2007-2014.

LEWIS, C.A., TALBOT, C.F. and VACQUIER, V.D. (1982). A protein from abalone sperm dissolves the egg vitelline layer by a non-enzymatic mechanism. Dev. Biol. 92: 227-239.

LYON, J.D. and VACQUIER, V.D. (1999). Interspecies chimeric sperm lysins identify regions mediating species-specific recognition of the abalone egg vitelline envelope. Dev. Biol. 214: 151-159.

MACLEAN, J.A., CHEN, M.G.A., WAYNE, C.M., BRUCE, S.R., RAO, M., MEISTRICH, M.L., MACLEOD, C. and WILKINSON, M.F. (2005). Rhox. A new homeobox gene cluster. Cel/120: 369-382.

MAH, S.A., SWANSON, W.J. and VACQUIER, V.D. (2005). Positive selection in the carbohydrate recognition domains of sea urchin sperm receptor for egg jelly (suREJ) proteins. Mol. Biol. Evol. 22: 533-541. 
MCCARTNEY, M.A. and LESSIOS, H.A. (2004). Adaptive evolution of sperm bindin tracks egg incompatibility in neotropical sea urchins of the genus Echinometra. Mol. Biol. Evol. 21: 732-45.

METZ, E.C., GOMEZ-GUTIERREZ, G. and VACQUIER, V.D. (1998a). Mitochondrial DNA and bindin gene sequence evolution among allopatric species of the sea urchin genus Arbacia. Mol. Biol. Evol. 15: 185-195.

METZ, E.C., KANE, R.E., YANAGIMACHI, H. and PALUMBI, S.R. (1994). Fertilization between closely-related sea-urchins is blocked by incompatibilities during sperm-egg attachment and early stages of fusion. Biol. Bull. 187: 23-34.

METZ, E.C. and PALUMBI, S.R. (1996). Positive selection and sequence rearrangements generate extensive polymorphism in the gamete recognition protein bindin. Mol. Biol. Evol. 13: 397-406.

METZ, E.C., ROBLES-SIKISAKA, R. and VACQUIER, V.D. (1998b). Nonsynonymous substitution in abalone sperm fertilization genes exceeds substitution in introns and mitochondrial DNA. Proc. Natl. Acad. Sci. USA 95: 10676-10681.

NUNNEY, L. and SCHUENZEL, E.L. (2006). Detecting natural selection at the molecular level: a reexamination of some «classic» examples of adaptive evolution. J. Mol. Evol. 62: 176-195.

NIXON, B., AITKEN, R.J. and MCLAUGHLIN, E.A. (2007). New insights into the molecular mechanisms of sperm-egg interaction. Cell. Mol. Life Sci. 64: 18051823.

PALUMBI, S.R. (1999). All males are not created equal: Fertility differences depend on gamete recognition polymorphisms in sea urchins. Proc. Natl. Acad. Sci. USA 96: 12632-12637.

PANHUIS, T.M., CLARK, N.L. and SWANSON, W.J. (2006). Rapid evolution of reproductive proteins in abalone and Drosophila. Philos. T. Roy. Soc. B 361: 261-268.

PANHUIS, T.M. and SWANSON, W.J. (2006). Molecular evolution and population genetic analysis of candidate female reproductive genes in Drosophila. GenetiCs 173: 2039-2047.

PODLAHA, O., WEBB, D.M., TUCKER, P.K. and ZHANG, J. (2005). Positive selection for indel substitutions in the rodent sperm protein CATSPER1. Mol. Biol. Evol. 22: 1845-1852.

RAM, K.R. and WOLFNER, M.F. (2007). Seminal influences: Drosophila Acps and the molecular interplay between males and females during reproduction. Integr. Comp. Biol. 47: 427-445

RANKIN, T.L., COLEMAN, J.S., EPIFANO, O., HOODBHOY, T., TURNER, S.G. CASTLE, P.E., LEE, E., GORE-LANGTON, R. and DEAN, J. (2003). Fertility and taxon-specific sperm binding persist after replacement of mouse sperm receptors with human homologs. Dev. Cel/5: 33-43.

RANKIN, T.L., TONG, Z.B., CASTLE, P.E., LEE, E., GORE-LANGTON, R., NELSON L.M. and DEAN, J. (1998). Human ZP3 restores fertility in Zp3 null mice without affecting order-specific sperm binding. Development 125: 2415-24.

RETIEF, J.D., WINKFEIN, R.J., DIXON, G.H., ADROER, R., QUERALT, R., BALLABRIGA, J. and OLIVA, R. (1993). Evolution of protamine P1 genes in primates. J. Mol. Evol. 37: 426-434.

RIGINOS, C. and MCDONALD, J.H. (2003). Positive selection on an acrosomal sperm protein, M7 lysin, in three species of the mussel genus Mytilus. Mol. Biol. Evol. 20: 200-207.

RIGINOS, C., WANG, D. and ABRAMS, A.J. (2006). Geographic variation and positive selection on M7 lysin, an acrosomal sperm protein in mussels (Mytilus spp.). Mol. Biol. Evol. 23: 1952-65

SCHULLY, S.D. and HELLBERG, M.E. (2006). Positive selection on nucleotide substitutions and indels in accessory gland proteins of the Drosophila pseudoobscura subgroup. J. Mol. Evol. 62: 793-802.

SHAW, A., FORTES, P.A.G., STOUT, C.D. and VACQUIER, V.D. (1995). Crystalstructure and subunit dynamics of the abalone sperm lysin dimer - egg envelopes dissociate dimers, the monomer is the active species. J. Cell Biol. 130: 1117-1125.

SHAW, A., MCREE, D.E., VACQUIER, V.D. and STOUT, C.D. (1993). The crystalstructure of lysin, a fertilization protein. Science 262: 1864-1867.

SINGH, R.S. and KULATHINAL, R.J. (2000). Sex gene pool evolution and speciation: A new paradigm. Genes Genet. Syst. 75: 119-130.

SINOWATZ, F., KOELLE, S. and TOEPFER-PETERSEN, E. (2001). Biosynthesis and expression of zona pellucida glycoproteins in mammals. Cells Tissues Organs 168: 24-35.

SPRINGER, S.A. and CRESPI, B.J. (2007). Adaptive gamete recognition divergence in a hybridizing Mytilus population. Evolution 61: 772-783.

SUTTON, K.A. and WILKINSON, M.F. (1997). Rapid evolution of a homeodomain: Evidence for positive selection. J. Mol. Evol. 45: 579-588.

SWANN, C.A., COOPER, S.J.B. and BREED, W.G. (2007). Molecular evolution of the carboxy terminal region of the zona pellucida 3 glycoprotein in murine rodents. Reproduction 133: 697-708.

SWANSON, W.J., CLARK, A.G., WALDRIP-DAIL, H.M., WOLFNER, M.F. and AQUADRO, C.F. (2001a). Evolutionary EST analysis identifies rapidly evolving male reproductive proteins in Drosophila. Proc. Natl. Acad. Sci. USA 98: 73757379 .

SWANSON, W.J. and VACQUIER, V.D. (1995). Extraordinary divergence and positive Darwinian selection in a fusagenic protein coating the acrosomal process of abalone spermatozoa. Proc. Natl. Acad. Sci. USA 92: 4957-4961.

SWANSON, W.J. and VACQUIER, V.D. (1997). The abalone egg vitelline envelope receptor for sperm lysin is a giant multivalent molecule. Proc. Natl. Acad. Sci. USA 94: 6724-6729.

SWANSON, W.J. and VACQUIER, V.D. (1998). Concerted evolution in an egg receptor for a rapidly evolving abalone sperm protein. Science 281: 710-712.

SWANSON, W.J. and VACQUIER, V.D. (2002a). Reproductive protein evolution. Annu. Rev. Ecol. Syst. 33: 161-79.

SWANSON, W.J. and VACQUIER, V.D. (2002b). The rapid evolution of reproductive proteins. Nat. Rev. Genet. 3: 137-144.

SWANSON, W.J., WONG, A., WOLFNER, M.F. and AQUADRO, C.F. (2004). Evolutionary expressed sequence tag analysis of Drosophila female reproductive tracts identifies genes subjected to positive selection. Genetics 168: 1457 1465.

SWANSON, W.J., YANG, Z., WOLFNER, M.F. and AQUADRO, C.F. (2001b). Positive Darwinian selection drives the evolution of several female reproductive proteins in mammals. Proc. Natl. Acad. Sci. USA 98: 2509-14.

TORGERSON, D.G., KULATHINAL, R.J. and SINGH, R.S. (2002). Mammalian sperm proteins are rapidly evolving: evidence of positive selection in functionally diverse genes. Mol. Biol. Evol. 19: 1973-80

TURNER, L.M., CHUONG, E.B. and HOEKSTRA, H.E. (2008) Comparative analysis of testis protein evolution in rodents. Genetics. (in press, doi: 10.1534/ genetics.107.085902)

TURNER, L.M. and HOEKSTRA, H.E. (2006). Adaptive evolution of fertilization proteins within a genus: Variation in ZP2 and ZP3 in deer mice (Peromyscus). Mol. Biol. Evol. 23: 1656-1669.

TURNER, L.M. and HOEKSTRA, H.E. (2008). Reproductive protein evolution within and between species: ZP3 sequence variation in Peromyscus trueiand P. gratus. Mol. Ecol. 17: 2616-2628.

WAEHLER, R., RUSSELL, S.J. and CURIEL, D.T. (2007). Engineering targeted viral vectors for gene therapy. Nat. Rev. Genet. 8: 573-587.

WAGSTAFF, B.J. and BEGUN, D.J. (2005a). Comparative genomics of accessory gland protein genes in Drosophila melanogaster and D. pseudoobscura. Mol. Biol. Evol. 22: 818-832.

WAGSTAFF, B.J. and BEGUN, D.J. (2005b). Molecular population genetics of accessory gland protein genes and testis-expressed genes in Drosophila mojavensis and D. arizonae. Genetics 171: 1083-1101.

WANG, X.X. and ZHANG, J.Z. (2007). Rapid evolution of primate ESX1, an X-linked placenta- and testis-expressed homeobox gene. Hum. Mol. Genet. 16: 20532060.

WASSARMAN, P., CHEN, J., COHEN, N., LITSCHER, E., LIU, C., QI, H. and WILLIAMS, Z. (1999). Structure and function of the mammalian egg zona pellucida. J. Exp. Zool. 285: 251-258.

WASSARMAN, P.M. (1999). Mammalian fertilization: Molecular aspects of gamete adhesion, exocytosis, and fusion. Ce//96: 175-183.

WILLIAMS, Z., LITSCHER, E.S., JOVINE, L. and WASSARMAN, P.M. (2006). Polypeptide encoded by mouse ZP3 exon-7 is necessary and sufficient for binding of mouse sperm in vitro. J. Cell. Physiol. 207: 30-39.

WILLIAMS, Z., LITSCHER, E.S. and WASSARMAN, P.M. (2003). Conversion of ser to thr residues at the sperm combining-site of mZP3 does not affect sperm 
receptor activity. Biochem. Biophys. Res. Commun. 301: 813-818.

WYCKOFF, G.J., WANG, W. and WU, C.I. (2000). Rapid evolution of male reproductive genes in the descent of man. Nature 403: 304-9.

YANG, Z. (2005). The power of phylogenetic comparison in revealing protein function. Proc. Natl. Acad. Sci. USA 102: 3179-3180.

YANG, Z. and SWANSON, W.J. (2002). Codon-substitution models to detect adaptive evolution that account for heterogeneous selective pressures among site classes. Mol. Biol. Evol. 19: 49-57.

YANG, Z.H., SWANSON, W.J. and VACQUIER, V.D. (2000). Maximum-likelihood analysis of molecular adaptation in abalone sperm lysin reveals variable selective pressures among lineages and sites. Mol. Biol. Evol. 17: 1446-1455.

ZHANG, Q., ZHANG, F., CHEN, X.H., WANG, Y.Q., WANG, W.Q., LIN, A.A., CAVALLI-SFORZA, L.L., JIN, L., HUO, R., SHA, J.H. et al. (2007). Rapid evolution, genetic variations, and functional association of the human sper- matogenesis-related gene NYD-SP12. J. Mol. Evol. 65: 154-161.

ZIGLER, K.S. and LESSIOS, H.A. (2003). Evolution of bindin in the pantropical sea urchin Tripneustes: Comparisons to bindin of other genera. Mol. Biol. Evol. 20: 220-231.

ZIGLER, K.S. and LESSIOS, H.A. (2004). Speciation on the coasts of the new world: Phylogeography and the evolution of bindin in the sea urchin genus Lytechinus. Evolution 58: 1225-1241.

ZIGLER, K.S., MCCARTNEY, M.A., LEVITAN, D.R. and LESSIOS, H.A. (2005). Sea urchin bindin divergence predicts gamete compatibility. Evolution59:23992404

ZIGLER, K.S., RAFF, E.C., POPODI, E., RAFF, R.A. and LESSIOS, H.A. (2003). Adaptive evolution of bindin in the genus Heliocidaris is correlated with the shift to direct development. Evolution 57: 2293-2302.

\section{Related, previously published Int. J. Dev. Biol. articles}

See our recent Special Issue Developmental Biology in Poland edited by Tarkowski, Maleszewski and Kloc at: http://www.ijdb.ehu.es/web/contents.php?vol=52\&issue=2-3

See our recent Special Issue Ear Development edited by Fernando Giraldez and Bernd Fritzsch at: http://www.ijdb.ehu.es/web/contents.php?vol=51\&issue=6-7

From the American to the European amphioxus: towards experimental Evo-Devo at the origin of chordates Jordi Garcia-Fernàdez, Senda Jiménez-Delgado, Juan Pascual-Anaya, Ignacio Maeso, Manuel Irimia, Carolina Minguillón, Èlia BenitoGutiérrez, Josep Gardenyes, Stéphanie Bertrand and Salvatore D’Aniello Int. J. Dev. Biol. (2008) 52: doi: 10.1387/ijdb.072436jg

Stanislaw Smreczynski's legacy and the Department of Zoology of the Jagiellonian University of Krakow (Poland) Mariusz K. Jaglarz Int. J. Dev. Biol. (2008) 52: 109-114

Emil Godlewski, Jr. (1875-1944) pioneer of embryology at the Jagiellonian University of Krakow (Poland) Leopold Sliwa Int. J. Dev. Biol. (2008) 52: 97-100

Evolutionary embryology resurrected in Japan with a new molecular basis: Nori Satoh and the history of ascidian studies originating in Kyoto during the 20th century

Shigeru Kuratani, Hiroshi Wada, Rie Kusakabe And Kiyokazu Agata Int. J. Dev. Biol. (2006) 50: 451-454

Morphological innovation through gene regulation: an example from Devonian Onychodontiform fish

Kenton S.W. Campbell and Richard E. Barwick

Int. J. Dev. Biol. (2006) 50: 371-375

Seed maturation: developing an intrusive phase to accomplish a quiescent state Jesús Vicente-Carbajosa and Pilar Carbonero

Int. J. Dev. Biol. (2005) 49: 645-651

Putting evo-devo into focus. An interview with Scott F. Gilbert Alexander T. Mikhailov

Int. J. Dev. Biol. (2005) 49: 9-16

Gametophyte interaction and sexual reproduction: how plants make a zygote Leonor C. Boavida, Ana Maria Vieira, Jörg D. Becker and José A. Feijó Int. J. Dev. Biol. (2005) 49: 615-632

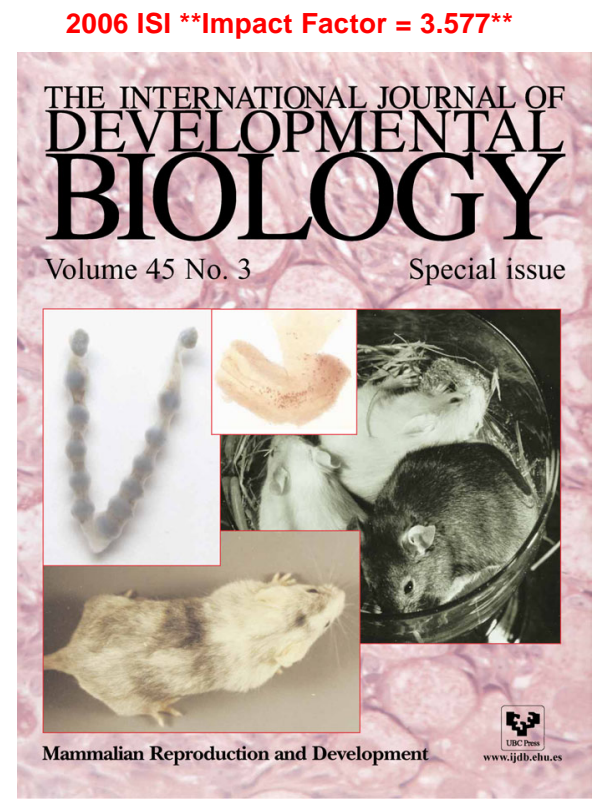

